\title{
In vivo anti-angiogenic effects further support the promise of the antineoplasic activity of methyl jasmonate
}

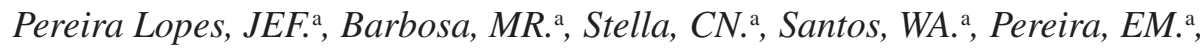 \\ Nogueira-Neto, J. ${ }^{\mathrm{b}}$,Augusto, EM. ${ }^{\mathrm{a}}$, Silva, LV. ${ }^{\mathrm{a}}$,Smaili, SS. ${ }^{\mathrm{c}}$ and Gomes, LF. ${ }^{\mathrm{a} *}$ \\ aDepartamento de Análises Clínicas e Toxicológicas, \\ Faculdade de Ciências Farmacêuticas, Universidade de São Paulo - USP, \\ Av. Professor Lineu Prestes, 580, Bl 17, CEP 05508-900, São Paulo, SP, Brazil \\ bDepartamento de Ciências Biológicas, Universidade Federal de São Paulo - UNIFESP, \\ Rua Arthur Riedel, 275, CEP 09972-270, Diadema, SP, Brazil \\ 'Departamento de Farmacologia, Universidade Federal de São Paulo - UNIFESP, \\ R. Botucatu, 862, $1^{\circ}$ andar, CEP 04023-900, São Paulo, SP, Brazil \\ *e-mail: lfgomes@usp.br \\ Received March 6, 2009 - Accepted April 3, 2009 - Distributed May 31, 2010
}

(With 2 figures)

\begin{abstract}
Molecular plant components have long been aimed at the angiogenesis and anti-angiogenesis pathways, and have been tested as sources for antineoplasic drugs with promising success. The present work deals with the anti-angiogenic effects of Methyl Jasmonate. Jasmonate derivatives were demonstrated to selectively damage the mitochondria of cancer cells. In vitro, 1-10 mM Methyl Jasmonate induced the cell death of the human umbilical vein endothelial cells (HUVEC) and the Murine melanoma cells (B16F10), while micromolar concentrations were ineffective. In vivo, comparable concentrations were toxic and reduced the vessel density of the Chorioallantoic Membrane of the Chicken Embryo (CAM). However, 1-10 $\mu \mathrm{M}$ concentrations produced a complex effect. There was increased capillary budding, but the new vessels were leakier and less organised than corresponding controls. It is suggested that not only direct toxicity, but also the drug effects upon angiogenesis are relevant to the antineoplasic effects of Methyl Jasmonate.
\end{abstract}

Keywords: methyl jasmonate, antiangiogenesis, CAM model, endothelial cell culture, HUVEC.

\section{Efeitos antiangiogênicos in vivo convalidam a atividade antineoplásica potencial do metiljasmonato}

\begin{abstract}
Resumo
Moléculas de origem vegetal são, há muito, conhecidas como substâncias ativas sobre as vias de angiogênese e antiangiogênese e foram testadas como fonte de drogas antineoplásicas com sucesso promissor. Este trabalho trata dos efeitos antiangiogênicos do Metiljasmonato, um protótipo da família dos derivados do ácido jasmônico, que danificam seletivamente a mitocôndria de células neoplásicas. In vitro, metiljasmonato 1-10 mM promoveu a morte celular de células endoteliais humanas de cordão umbilical (HUVEC) e de melanoma murino (B16F10); concentrações micromolares foram inócuas. In vivo, concentrações equivalentes foram tóxicas e reduziram a densidade de vasos em membranas corioalantoicas de embrião de galinha (CAM). Entretanto, concentrações entre 1-10 $\mu$ M produziram um efeito complexo. Ocorreu aumento no brotamento capilar, mas os novos vasos apresentaram-se frágeis e menos organizados que os controles correspondentes. Sugere-se que, além da toxicidade direta contra as células tumorais, a ação do metiljasmonato sobre a angiogênese seja relevante para seu efeito antineoplásico.
\end{abstract}

Palavras-chave: metiljasmonato, antiangiogênese, modelo da CAM, cultura de células endoteliais, HUVEC.

\section{Introduction}

Jasmonate derivatives are recognised as cytotoxic substances against tumor cells that induce apoptosis in malignant cells through different pathways, while the corresponding normal cell types were resistant, highlighting the therapeutic potential of these molecules as antineoplasic substances.(Fingrut and Flescher, 2002). The mitochondrial membrane is the likely target for the p53-independent Jasmonates cytotoxicity (Rotem et al., 2005). Other targets were considered, taking into account the structural similarities between Jasmonate derivatives 
and prostaglandins (Conti et al., 2007). Remarkably, endothelial cell lineages have never been tested for Jasmonates toxicity, despite its known susceptibility to apoptosis. Endothelial and tumor cells share mitochondrial structural and functional peculiarities that prompted us to hypothesise that both cell types could present analogous susceptibility to Jasmonates. Indeed, both cell types present anaerobic metabolism dependence (Gatenby, R.A.; Gillies, 2004) and higher mitochondrial heterogeneity than most of the other cell types (Collins et al., 2002; De Giorgi et al., 2000). Indeed, Methyl Jasmonate was now found to be an anti-angiogenic compound both in Endothelial Cell cultures in vitro and in the model of angiogenesis in Chicken Embryo Chorioallantoic Membrane in vivo. Altogether, the wellknown cytotoxicity of Methyl Jasmonate against cancer cells and its in vivo anti-angiogenic action, adjudicate its use for therapeutic purposes.

\section{Materials and Methods}

\subsection{Preparation of methyl jasmonate}

The commercial methyl (1R, 2R)-3-Oxo-2-(2Z)-2pentenyl-cyclopentanoacetate (Methyl dihydrojasmonate 96\% cis-trans mixture Sigma Aldrich - Missouri - USA) was diluted in absolute ethanol (Merck). It was analysed by gas chromatography mass spectrometry (GC-MS) in a Focus chromatograph coupled to a PolarisQ mass spectrometer equipped with automatic injector and ion trap TriPlus, as described (Mueller et al., 2006). Samples $(1 \mu \mathrm{L})$ were splitless mode injected at $250{ }^{\circ} \mathrm{C}$, under $0.6 \mathrm{~mL} / \mathrm{min}$ He flow. Each chromatogram was initiated at $100{ }^{\circ} \mathrm{C}$, for 1 minute, and then the temperature was increased $10{ }^{\circ} \mathrm{C} / \mathrm{min}$ until $300{ }^{\circ} \mathrm{C}$, and kept constant for 4 minutes. Transfer line and detector were at 250 and $200{ }^{\circ} \mathrm{C}$, respectively. Full scan - m/z: 50-400 Mass spectrum was obtained and compared with the literature (Schmelz et al., 2003, Mueller et al., 2006). The compound was employed either purely or dissolved in ethanol for all the biological assays.

\subsection{In vitro toxicity and endothelial cell cultures}

Human umbilicalcordveinendothelialcells(HUVEC) were grown $5 \times 10^{4}$ cells $/ \mathrm{mL}$ in RPMI 1640 containing $10 \%$ fetal calf serum in 96 wells plates. Adherence was obtained after 3-6 hours at $37{ }^{\circ} \mathrm{C} / 5 \% \mathrm{CO}_{2}$. The MTT test was performed as described (Denizot and Lang, 1986, modified). Briefly, adhered cells were exposed to Methyl Jasmonate in serum free RPMI for 24 hours. After this time, the medium was removed through soaking and then each well was added with $50 \mu \mathrm{L}$ of MTT $\left(1 \mathrm{mg} \cdot \mathrm{mL}^{-1}\right)$ in phenol red free RPMI. The plates were shaken for 3 hours and the medium was removed by inversion. MTT Formazan was dissolved through swirling with $100 \mu \mathrm{L}$ of DMSO for 30 minutes and measured in a spectrophotometric ELISA reader at $580 \mathrm{~nm}$. Controls were processed as samples, excluding the Methyl Jasmonate. Growth curves were followed for 96 hours after adhered cells were exposed to Methyl Jasmonate in RPMI 1640 containing $10 \%$ fetal calf serum. After trypsinization and quantitative suspension of each individual well content in an isotonic solution of Trypan Blue, viable cells were counted twice in a $0.4 \mathrm{~mm}^{3}$, using a Neubauer chamber. Individual data points were obtained as a mean of independent triplicates, at 24 hours intervals. VEGF production was analysed in the cell culture supernatants after 4 hours exposition to known concentrations of Methyl Jasmonate with the commercial ELISA kit (R\&D System, Minneapolis, Mn, USA, cat n. DY293B). Cell death was evaluated by cell cycle analyses performed using Flow Cytometry (FACScalibur, BD, USA). In this case cells were used after 18 hours exposition and incubation with propidium iodide. To estimate the possible involvement of cell death versus autophagy, cells were incubated with Acridine Orange and analysed by Flow Cytometry as well (Klionsky et al., 2008).

\subsection{In vivo angiogenesis assay (CAM model)}

The effect of Methyl Jasmonate on angiogenesis was studied in the incubated eggs lying on a hatching tray, as described (Ribatti et al., 1996; 2000). Recent 24 hours postured eggs of $18 \mathrm{~m}$ old Gallus Domesticus, white and weighing approximately $45 \mathrm{~g}$, were incubated in a brooder (Zagas - São Paulo-SP) at 51\% internal humidity and $37.2^{\circ} \mathrm{C}$. After 5 days of incubation, the eggs were taken to a lamellar flow camera and $5 \mathrm{~mL}$ of albumin were removed through a small hole produced in the air chamber, with a $27 \times 5 \mathrm{~mm}$ disposable needle coupled to a $5 \mathrm{~mL}$ sterile syringe. The left needle's hole, at the external egg shell air chamber, was sealed with a piece of sterile tape. After this procedure, a piece of approximately $2 \mathrm{~cm}^{2}$ of the egg shell was carefully removed in order to provide an observation window in the upper face of the egg. After confirmation of the existence and viability of the embryo, the window was sealed with transparent sterile tape, avoiding external contact. Incubation was continued for another 120 hours, and was inspected each day with the development and viability of the embryo. At the end of this period, the tape was again opened at the lamellar flow camera and a circular filter, sterile, $5 \mathrm{~mm}$ in diameter was deposited on the outside of the yolk sac. This filter serves as a support for the application of different doses of Methyl Jasmonate. The collection of the material occurred after the euthanasia of the embryo by hypothermia and further fixation with the use of formalin for a 20 minutes period. The CAM was then cut around the disc or the site of application and washed with phosphate-buffered saline isosmotic ice, placed, well distended, between slide and coverslip and photographed with the programme ACT-2U by a digital DS-U1 camera attached to a stereoscopic Nikon SMZ1800 microscope at $2 \times$ magnification, standardised illumination, shadow regulation and TIFF image resolution. The images were analysed for vessel densities with the programme Image J. Results were expressed in the number of pixels of the images obtained after preset threshold binary conversion (Areas). 


\section{Results}

MeJa consistently impaired vascular growth in this Chorioallantoic model of angiogenesis, but its effects seemed to occur through at least two different mechanisms depending on the applied dosage. Lower concentrations typically $(<100 \mu \mathrm{M}$ MeJa) resulted in disordered vascular growth, forming lots of capillary anastomosis and dysfunctional vessels, compatible with VEGF withdrawing. On the other hand, milimolar concentrations significantly reduced the capillary growth, an effect which is most likely associated with direct cytotoxicity. (Figure 1). In order to better understand the in vivo observed effect, cell culture effects were characterised. Both the classical endothelial cell lineage, HUVEC, and a MeJa susceptible neoplasic cell lineage, B16F10 murine melanoma, were studied. Melanoma cells and HUVECs presented similar susceptibility to MeJa cytotoxical effects in the MTT test (Figure 2). Toxic concentrations were in the 1-10 $\mathrm{mM}$ range for both cells. Less confluent cultures exposed to 1-10 $\mu \mathrm{M}$ MeJa consistently produced higher MTT reduction than corresponding controls (not shown). However, growth curves failed to demonstrate increased cell proliferation, despite cytotoxicity being unequivocally shown at 1-10 mM MeJa (Figure 2).

Flow Cytometry studies confirmed apoptotic cell death of HUVECs with $10 \mathrm{mM}$ MeJa, while $1 \mathrm{mM}$ MeJa induced cell cycle $\mathrm{G}_{1}$ arrest, as shown in (Table 1). In endothelial cells and at micromolar concentrations, MeJa also induced early effects such as morphological changes (multinucleation, microvacuolation, cell shrinkage and apoptotic bodies), and metabolic changes, revealed through combined Acridine Orange/Propidium Iodide probing and decreased VEGF production (Table 1).
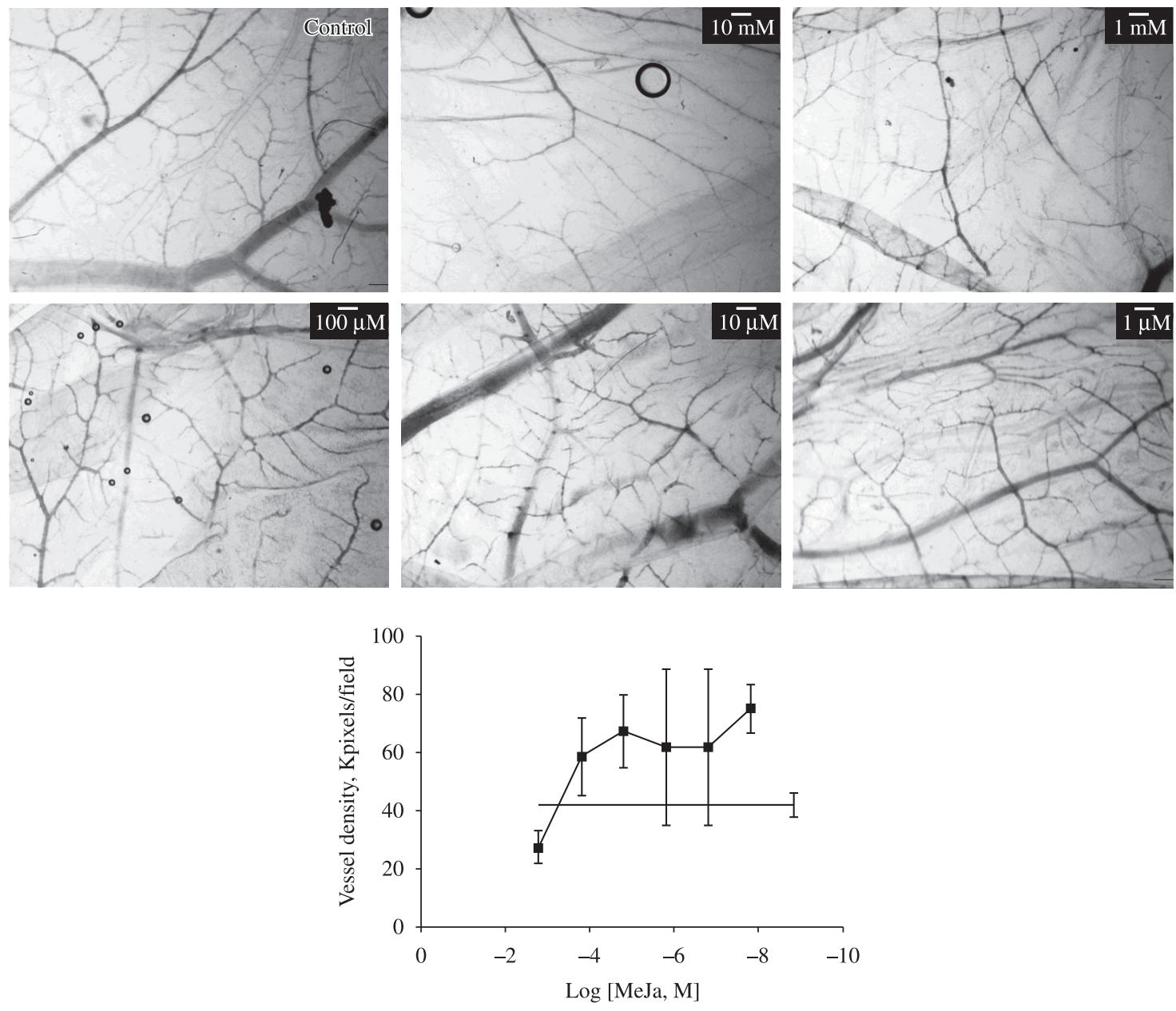

Figure 1. Typical aspects of the MeJa in vivo effects upon the angiogenesis within the Chicken Embryo Chorioallantoic Membrane. Unexposed control and log-based series of MeJa exposed membranes as exemplified, with the corresponding concentration in the upper corner of each image. Lower right panel shows the measured mean \pm standard deviation vessel areas for independent samples, $(\mathrm{n} \geq 3)$, measured after binarization of the digital images as described in Materials and Methods. Results were plotted as pixel densities in relation to molar concentrations of MeJa, in a linear $\times \log$ format. Image size: $1280 \times 960$ pixels. Optical magnification: $2 \times$. 

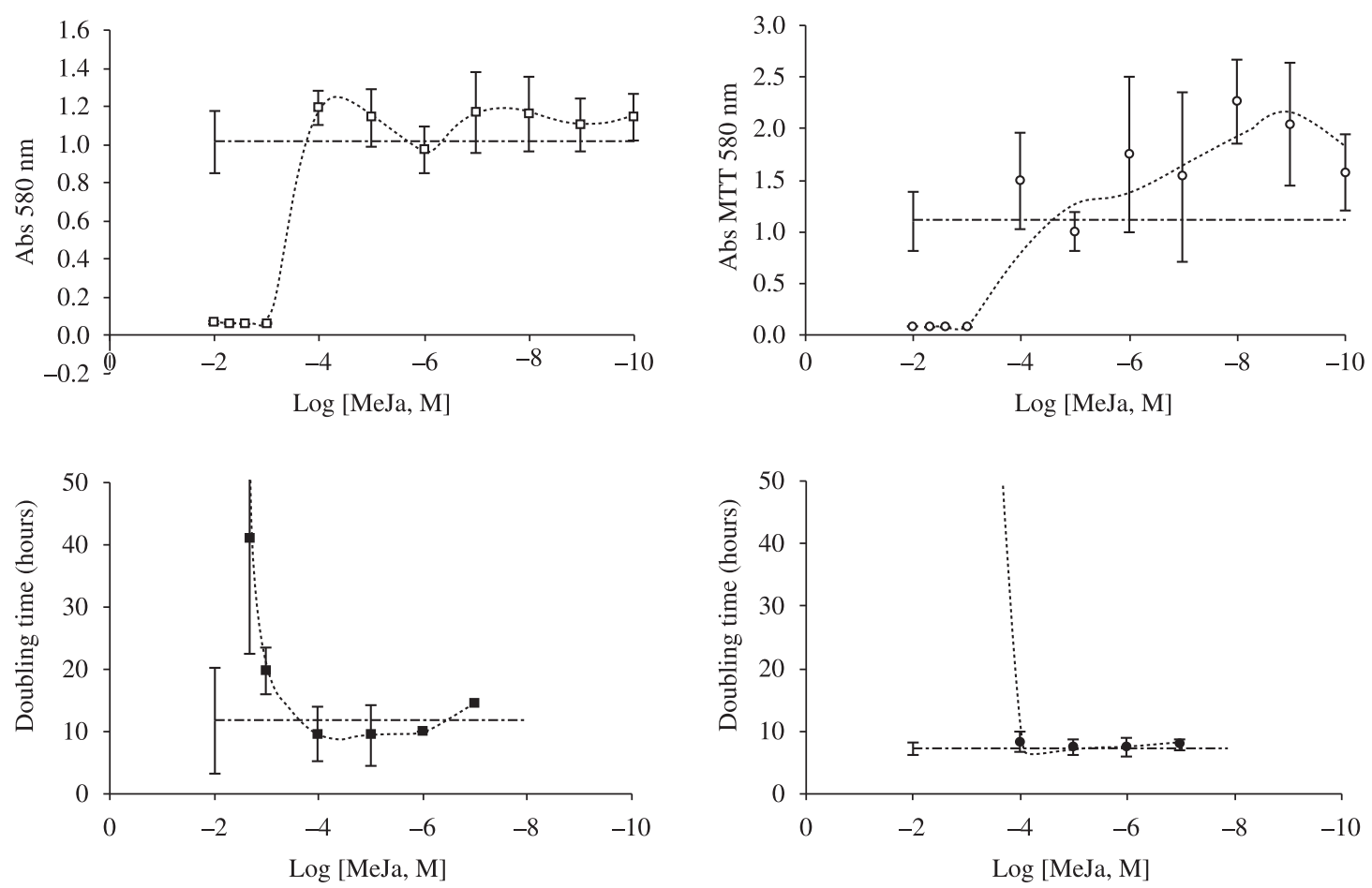

Figure 2. MeJa citotoxicity for HUVEC ( $\square$, left panels) and B16F10 (o right panels) cells measured through MTT reduction test, after 24 hours exposition (open symbols) or expressed as log phase doubling times, in 5 days cultures (closed symbols).

Table 1. Cell Cycle and metabolic effects of MeJa upon HUVEC cells.

\begin{tabular}{|c|c|c|c|c|c|}
\hline & \multicolumn{3}{|c|}{ Cell cycle profile, 18 hours } & \multirow{2}{*}{$\begin{array}{l}\text { Acridine orange } \\
\text { labelled cells }(\%)\end{array}$} & \multirow{2}{*}{$\begin{array}{c}\text { VEGF }(\mathrm{pg} / \mathrm{mL}) \\
2 \times 106 \text { cells, } 4 \text { hours }\end{array}$} \\
\hline & Dead cells (\%) & G0/G1 (\%) & G2/S (\%) & & \\
\hline Untreated & 6 & 59 & 35 & $6.3 \pm 0,1$ & $431 \pm 67$ \\
\hline $10 \mathrm{mM}$ & 93 & 5 & 2 & n.d. ${ }^{\mathrm{a}}$ & n.d. ${ }^{\mathrm{a}}$ \\
\hline $1 \mathrm{mM}$ & 13 & 72 & 15 & $6.2 \pm 0.1$ & $566 \pm 31$ \\
\hline $100 \mu \mathrm{M}$ & 8 & 56 & 36 & $6.7 \pm 0.3$ & $450 \pm 30$ \\
\hline $10 \mu \mathrm{M}$ & 7 & 60 & 33 & $9.0 \pm 0.5$ & $319 \pm 12^{\mathrm{b}}$ \\
\hline
\end{tabular}

${ }^{a}$ n.d. - not determined. Data point interpretation precluded due to extensive cell death. $(\mathrm{n}=3) ;{ }^{\mathrm{b}}($ Control $\times 10 \mu \mathrm{M}$ treated, $\mathrm{p}<0.05)$.

\section{Discussion}

Our results demonstrated, for the first time to our knowledge, the influence of MeJa in angiogenic development in vivo, demonstrating its potential as a therapeutic option for cancer treatment.

It should be noted that the functional proximity among MeJa and cyclopentenone prostaglandins has been addressed by Conti (Conti, 2006). These compounds share with MeJa the ability to induce cancer cell cycle G1 arrest at concentrations slightly lower than those employed to promote overt cell death (Hsiang and Straus, 2002). Also, the 2-cyclopentenone ring itself was reported to be pro-apoptotic to HUVECs at concentrations as low as $0.25 \mu \mathrm{M}$ (Vosseler and Weber, 2003).

Indeed, the cell cycle G1 arrest and death induction of normal endothelial cells from the HUVEC lineage as reported in Table 1, also leads us to consider similar targets, despite MeJa lack of the minimal cyclopentenone structure (Vosseler and Weber, 2003). The putative cytotoxicity mechanisms of the cyclopentenone prostaglandins are NFKB activation blockage and PPAR $\gamma$ activation (Bishop-Bailey and Hla, 1999; Straus et al, 2000; Rossi et al., 2000). Both pathways are known to be relevant for the control of vascular growth and differentiation in vivo, as the transcription signals promote VEGF and other growth factors expression. In miofibroblasts, the activation of the peroxisome proliferator-activated receptor (PPAR)- $\gamma$ by its agonists induces VEGF expression while simultaneously decreasing inflammation (NF-KB) (Chintalgattu et al., 2007). VEGFR2 expression is an additional target of PPAR activation in endothelial cells. In HUVECs, an anti-angiogenic effect was reported for 
PGJ2, a PPAR agonist which simultaneously produces a moderate VEGF increase and a transient and self-limited VEGFR2 decrease (Funovics et al., 2006). It is important to mention that these mechanisms synergise, but are not necessarily interdependent. On the other hand, the mitochondria proved to be the main target to MeJa induced cell death (Rotem et al., 2005; Goldin et al., 2007). Nonetheless, despite HUVECs and B16F10 melanoma cells presenting similar susceptibility to the toxic milimolar doses of MeJa, as both cell types were unaffected by lower MeJa doses (Figure 2), VEGF production showed a discrete $20 \%$ increase at 4 hours exposition (Table 1) and this probably represents an early and transient survival signal.

It is speculated if VEGF increases and VEGFR2 transient decreases, they could play a role in vascular leakiness. Vascular permeability is controlled by VEGF and angiopoietins which bind to a tyrosine kinase receptor. Increased VEGF promotes receptor cleavage and inhibits vascular stabilisation mediated by angiopoietin-1 (Thurston et al, 1999; Findley et al., 2007). On the other hand, VEGF withdrawn in the presence of Angiopoietin-2 results in low vessel maturation, increased proliferation and leakiness.

In accordance with previously reported effects of the cyclopentenone prostaglandins (Funovics et al., 2006), in vivo effects were surprisingly intense, not only at the toxic milimolar doses, but also in micromolar concentration ranges. Convergent, but distinct, effects were seen in milimolar and micromolar concentrations of MeJa. Higher doses impacted vessel growth, resulting in lower densities, probably after gross energy metabolism impairment and increased cell death (Figure 1) following the transient stimulation of VEGF production. On the other hand, an in vivo increased and disordered proliferation associated to dysfunctional vessels in the CAMs exposed to lower doses (Figure 1). This effect is probably dependent on more complex signal transduction. We could not find important cell cycle effects upon HUVEC cells in this concentration range, except for a discrete increase of the Acridine Orange labelling at $10 \mu \mathrm{M}$ (Table 1), which may indicate one attempt of the cells to survive by stimulation of some autophagy. Conversely, with the increase in concentration, autophagy would not be present and apoptotic cell death would occur. Redox imbalance are surely involved in the cell senescence mechanism (Muller, 2009), however the results presented in Table 1 only allow us to consider senescence induction among the possibilities of MeJa cytotoxicity towards endothelial cells at milimolar, but not at micromolar concentration range.

Decreased in vitro VEGF production was observed at micromolar doses, which is compatible with the pattern of vascular impairment observed in vivo. Similar effects of VEGF withdrawn were described in tumors and in the uterine epithelium (Benjamin and Keshet, 1997, Matsumoto et al., 2002). VEGF withdrawn effects of MeJa can derive from the suppression of COX-2 transcription through either AP-1 dependent and independ- ent mechanisms (Subbaramaiah et al., 2001). Several of the known anti-neoplastic properties of PGJ 2 and PPAR $\gamma$ ligands rely on their ability to inhibit COX-2 expression and PG biosynthesis (Simmons et al., 2004). COX-2 inhibition is particularly impor tant in the neoplastic, as well as in the embryonic, microenvironment. COX-2 expression is driven by shear stress and hypoxia and is much less relevant in normal than in rapid growing and inflamed or regenerating tissues (Greenhough et al., 2009). The COX-2/PGE2 pathway has multiple pro-angiogenic effects. PGE2 can enhance the hypoxia induced factordependent expression of VEGF-A, and also the expression of other VEGFs and chemokine receptors acting upon microvessel assembly (Su et al., 2004; Pan et al., 2008). The COX-2 expression and the consequent PGE2 production are higher in the migrating cells of developing sprouts than in the confluent endothelial monolayer of mature vessels. In the actively growing tumor vessels, PGE2 acts as an autocrine signal for vascular sprouting (Jiang et al., 2004). The inhibition of the COX-2/PGE2 pathway is therefore expected to constrain the production of functional neovessels inside tumors. Moreover, there are other relevant mechanisms implied in vasculature impairment and leakage. Some of them can only be disclosed in complex models and not in the monotype cell cultures, as they stand for the endothelial cells, pericytes, and smooth muscle cells interactions (Lee et al., 2006). PGJ2 was reported to promote adipose conversion in a variety of cell lines, to block myogenesis through inhibition of Myo D gene expression, and to induce the PPAR $\gamma$ angiopoietin related (PGAR) protein expression in endothelial cells (Hu et al., 1995, Hunter et al., 2001, Salcedo et al., 2003). This close angiopoietin-2 related protein is particularly present in placental tissues and accounts for vascular remodelling (Yoon et al., 2000). Whichever mechanism predominates in vivo, it is proposed that MeJa can make the neovessels so leaky as to cause tumor destruction.

Critical imbalance effects of a myriad of pro- and anti-angiogenic growth factors were obviously favoured within the extra-embryonic egg tissue model. Outstandingly, presented results disclose the synergistic and multitargeted actions of MeJa. In conclusion, mechanistic insight was provided through paired endothelial cell cultures and in vivo assays. The converging in vivo anti-angiogenic actions adds to the promising therapeutic application of Methyl Jasmonate as an antineoplasic substance.

Acknowledgements - The authors specially thank Dr. Eliezer Flescher from Tel-Aviv University for his helpful advisory support, Dr. Irene Yan for allowing us to use the stereoscopic microscope and for kindly managing the egg purchase and distribution among several research groups, Ms. Priscila Denapoli from CINTERGEN - UNIFESP for analysing the VEGF samples, Ms. Moema Rodrigues dos Santos for the help with the reference formats, and Ms. Marina Barbosa Pereira Lopes from Boston College for reviewing the manuscripts. Dr. Ligia Gomes received a scholarship from FAPESP (07/577285 ). The present work was partially supported by FUNAMA. 


\section{References}

BENJAMIN, LE. and KESHET, E., 1997. Conditional switching of vascular endothelial growth factor (VEGF) expression in tumors: induction of endothelial cell shedding and regression of hemangioblastoma-like vessels by VEGF withdrawal. Proceedings of the National Academy of Sciences of the United States of America, vol. 94, no. 16, p. 8761-8766.

BISHOP-BAILEY, D. and HLA, T., 1999. Endothelial cell apoptosis induced by the peroxisome proliferator-activated receptor (PPAR) ligand 15-deoxy- $\Delta 12$, 14-prostaglandin J2. Journal of Biological Chemistry, vol. 274, no. 24, p. $17042-17048$.

CHINTALGATTU, V., HARRIS, GS., AKULA, SM. and KATWA, LC., 2007. PPAR- $\gamma$ agonists induce the expression of VEGF and its receptors in cultured cardiac myofibroblasts. Cardiovascular Research, vol. 74, no. 1, p. 140-150.

COLLINS, TJ., BERRIDGE, MJ., LIPP, P. and BOOTMAN, MD., 2002. Mitochondria are morphologically and functionally heterogeneous within cells. The EMBO Journal, vol. 21, no. 7, p. 1616-1627.

CONTI, M., 2006. Cyclopentenone: a special moiety for anticancer drug design. Anticancer Drugs, vol. 17, no. 9, p. 1017-1022.

CONTI, M., 2007. A perspective on rational drug design with cyclopentenone: targeting the proteome with the cyclopentenone chemical moiety. Expert Opinion on Drug Discovery, vol. 2, no. 9 , p. 1-7.

DENIZOT, F. and LANG, R., 1986. Rapid colorimetric assay for cell growth and survival: modifications to the tetrazolium dye procedure giving improved sensitivity and reliability. Journal of Immunological Methods, vol. 89, no. 2, p. 271-277.

FINDLEY, CM., CUDMORE, MJ., AHMED, A. and KONTOS, CD., 2007. VEGF Induces Tie2 shedding via a phosphoinositide 3-kinase/akt-dependent pathway to modulate Tie2 signaling. Arteriosclerosis, Thrombosis and Vascular Biology, vol. 27, no. 12 , p. 2619-2626.

FINGRUT, O. and FLESCHER, E., 2002. Plant stress hormones suppress the proliferation and induce apoptosis in human cancer cells. Leukemia, vol. 16, no. 4, p. 608-616.

FUNOVICS, P., BROSTJAN, C., NIGISCH, A., FILA, A., GROCHOT, A., MLECZKO, K., WAS, H., WEIGEL, G., DULAK, J. and JOZKOWICZ, A., 2006. Effects of 15d-PGJ2 on VEGF-induced angiogenic activities and expression of VEGF receptors in endothelial cells. Prostaglandins and Other Lipid Mediators, vol. 79, no. 3-4, p. 230-244.

GATENBY, RA. and GILLIES, RJ., 2004. Why do cancer have a high aerobic glycolysis? Nature Reviews Cancer, vol. 4, no. 11 , p. 891-899.

GIORGI, F. and LARTIGUE, L., ICHAS, F., 2000. Electrical coupling and plasticity of the mitochondrial network. Cell Calcium, vol. 28, no. 5-6, p. 365-370.

GOLDIN, N., HEYFETS, A., REISCHER, D. and FLESCHER, E., 2007. Mitochondria-mediated ATP depletion by anti-cancer agents of the Jasmonate family. Journal of Bioenergetics and Biomembranes, vol. 39, no. 1, p. 51-57.

GREENHOUGH, A., SMARTT, HJM., MOORE, AE., ROBERTS, HR., WILLIAMS, AC., PARASKEVA, C. and
KAIDI, A., 2009. The COX-2/PGE 2 pathway: key roles in the hallmarks of cancer and adaptation to the tumour microenvironment. Carcinogenesis, vol. 30, no. 3, p. 377-386.

HU, E., TONTONOZ, P. and SPIEGELMAN, BM., 1995. Transdifferentiation of myoblasts by the adipogenic transcription factors PPAR $\gamma$ and $\mathrm{C} / \mathrm{EBP} \alpha$. Proceedings of the National Academy of Sciences of the United States of America, vol. 92 , no. 21 , p. $9856-9860$.

HUNTER, JG., DELFT, MF., Van RACHUBINSKI, RA. and CAPONE, JP., 2001. Peroxisome proliferator-activated receptor $\gamma$ ligands differentially modulate muscle cell differentiation and MyoD gene expression via peroxisome proliferator-activated receptor $\gamma$-dependent and -independent pathways. Journal of Biological Chemistry, vol. 276, no. 41, p. 38297-38306.

JIANG, H., WEYRICH, AS., ZIMMERMAN, GA. and McINTYRE, TM., 2004. Endothelial cell confluence regulates cyclooxygenase-2 and prostaglandin $\mathrm{E}_{2}$ production that modulate motility. Journal of Biological Chemistry, vol. 279, no. 53 , p. 55905-55913.

KLIONSKY, DJ., ABELIOVICH, H., AGOSTINIS, P., AGRAWAL, DK., ALIEV, G., ASKEW, DS., BABA, M., BAEHRECKE, EH., BAHR, BA., BALLABIO, A., BAMBER, BA., BASSHAM, DC., BERGAMINI, E., BI, X., BIARD-PIECHACZYK, M., BLUM, JS., BREDESEN, DE., BRODSKY, JL., BRUMELL, JH., BRUNK, UT., BURSCH, W., CAMOUGRAND, N., CEBOLLERO, E., CECCONI, F., CHEN, Y., CHIN, LS., CHOI, A., CHU, CT., CHUNG, J., CLARKE, PG., CLARK, RS., ClARKE, SG., ClAVÉ, C., CLEVELAND, JL., CODOGNO, P., COLOMBO, MI., COTOMONTES, A., CREGG, JM., CUERVO, AM., DEBNATH, J., DEMARCHI, F., DENNIS, PB., DENNIS, PA., DERETIC, V., DEVENISH, RJ., DI SANO, F., DICE, JF., DIFIGLIA, M., DINESH-KUMAR, S., DISTELHORST, CW., DJAVAHERIMERGNY, M., DORSEY, FC., DRÖGE, W., DRON, M., DUNN JR., WA., DUSZENKO, M., EISSA, NT., ELAZAR, Z., ESCLATINE, A., ESKELINEN, EL., FÉSÜS, L., FINLEY, KD., FUENTES, JM., FUEYO, J., FUJISAKI, K., GALLIOT, B., GAO, FB., GEWIRTZ, DA., GIBSON, SB., GOHLA, A., GOLDBERG, AL., GONZALEZ, R., GONZÁLEZ-ESTÉVEZ, C., GORSKI, S., GOTTLIEB, RA., HÄUSSINGER, D., HE, YW., HEIDENREICH, K., HILL, JA., HØYER-HANSEN, M., HU, X., HUANG, WP., IWASAKI, A., JÄÄTTELÄ, M., JACKSON, WT., JIANG, X., JIN, S., JOHANSEN, T., JUNG, JU., KADOWAKI, M., KANG, C., KELEKAR, A., KESSEL, DH., KIEL, JA., KIM, HP., KIMCHI, A., KINSELLA, TJ., KISELYOV, K., KITAMOTO, K., KNECHT, E., KOMATSU, M., KOMINAMI, E., KONDO, S., KOVÁCS, AL., KROEMER, G., KUAN, CY., KUMAR, R., KUNDU, M., LANDRY, J., LAPORTE, M., LE, W., LEI, HY., LENARDO, MJ., LEVINE, B., LIEBERMAN, A., LIM, KL., LIN, FC., LIOU, W., LIU, LF., LOPEZ-BERESTEIN, G., LÓPEZ-OTÍN, C., LU, B., MACLEOD, KF., MALORNI, W., MARTINET, W., MATSUOKA, K., MAUTNER, J., MEIJER, AJ., MELÉNDEZ, A., MICHELS, P., MIOTTO, G., MISTIAEN, WP., MIZUSHIMA, N., MOGRABI, B., MONASTYRSKA, I., MOORE, MN., MOREIRA, PI., MORIYASU, Y., MOTYL, T., MÜNZ, C., MURPHY, LO., NAQVI, NI., NEUFELD, TP., NISHINO, I., NIXON, RA., NODA, T., NÜRNBERG, B., OGAWA, M., OLEINICK, NL., OLSEN, LJ., OZPOLAT, B., PAGLIN, S., PALMER, GE., PAPASSIDERI, I., PARKES, M., PERLMUTTER, DH., PERRY, G., PIACENTINI, M., PINKAS-KRAMARSKI, R., PRESCOTT, M., PROIKASCEZANNE, T., RABEN, N., RAMI, A., REGGIORI, F., ROHRER, B., RUBINSZTEIN, DC., RYAN, KM., 
SADOSHIMA, J., SAKAGAMI, H., SAKAI, Y., SANDRI, M., SASAKAWA, C., SASS, M., SCHNEIDER, C., SEGLEN, PO., SELEVERSTOV, O., SETTLEMAN, J., SHACKA, JJ., SHAPIRO, IM., SIBIRNY, A., SILVA-ZACARIN, EC., SIMON, HU., SIMONE, C., SIMONSEN, A., SMITH, MA., SPANELBOROWSKI, K., SRINIVAS, V., STEEVES, M., STENMARK, H., STROMHAUG, PE., SUBAUSTE, CS., SUGIMOTO, S., SULZER, D., SUZUKI, T., SWANSON, MS., TABAS, I., TAKESHITA, F., TALBOT, NJ., TALLÓCZY, Z., TANAKA, K., TANAKA, K., TANIDA, I., TAYLOR, GS., TAYLOR, JP., TERMAN, A., TETTAMANTI, G., THOMPSON, CB., THUMM, M., TOLKOVSKY, AM., TOOZE, SA., TRUANT, R., TUMANOVSKA, LV., UCHIYAMA, Y., UENO, T., UZCÁTEGUI, NL., VAN DER KLEI, I., VAQUERO, EC., VELLAI, T., VOGEL, MW., WANG, HG., WEBSTER, P., WILEY, JW., XI, Z., XIAO, G., YAHALOM, J., YANG, JM., YAP, G., YIN, XM., YOSHIMORI, T., YU, L., YUE, Z., YUZAKI, M., ZABIRNYK, O., ZHENG, X., ZHU, X. and DETER, RL., 2008. Guidelines for the use and interpretation of assays for monitoring autophagy in higher eukaryotes. Autophagy, vol. 4, no. 2, p. 151-175.

LEE, A., FRISCHER, J., SERUR, A., HUANG, J., BAE, JO., KORNFIELD, ZN., ELJUGA, L., SHAWBER, CJ., FEIRT, N., MANSUKHANI, M., STEMPAK, D., BARUCHEL, S., BENDER, JG., KANDEL, JJ. and YAMASHIRO, DJ., 2006. Inhibition of cyclooxygenase-2 disrupts tumor vascular mural cell recruitment and survival signaling. Cancer Research, vol. 66 , no. 8 , p. $4378-4384$.

MATSUMOTO, H., MA, W., DAIKOKU, T., ZHAO, X., PARIA, BC., DAS, SK., TRZASKOS, JM. and DEY, SK., 2002. Cyclooxygenase-2 differentially directs uterine angiogenesis during implantation in mice. Journal of Biological Chemistry, vol. 277 , no. 32 , p. $29260-29267$.

MUELLER, MJ., MÈNE-SAFFRANE, L., GRUN, C., KARG, K. and FARMER, EE., 2006. Oxylipin analysis methods. Plant Journal, vol. 45, no. 4, p. 472-489.

MULLER, M., 2009. Cellular senescence: molecular mechanisms, in vivo significance and redox considerations. Antioxidant \& Redox Signaling, vol. 11, no. 1, p. 59-98.

PAN, MR., HOU, MF., CHANG, HC. and HUNG, WC., 2008. Cycloxygenase-2 up regulates CCR7 via EP2/EP4 receptor signaling pathways to enhance lymphatic invasion of breast cancer cells. Journal of Biological Chemistry, vol. 283, no. 17, p. $11155-11163$.

RIBATTI, D., VACCA, A., RONCALI, L. and DAMMACCO, F., 1996. The chick embryo chorioallantoic membrane as a model for in vivo research on angiogenesis. International Journal of Developmental Biology, vol. 40, no. 6, p. 1189-1197.

RIBATTI, D., VACCA, A., RONCALI, L. and DAMMACCO, F., 2000. The chick embryo chorioallantoic membrane as a model for in vivo research on anti-angiogenesis. Current Pharmaceutical Biotechnology, vol. 1, no. 1, p. 73-82.

ROSSI, A., KAPAHI, P., NATOLI, G., TAKAHASHI, T., CHEN, Y., KARIN, M. and SANTORO, MG., 2000. Anti-inflammatory cyclopentenone prostaglandins are direct inhibitors of IKB kinase. Nature, vol. 403, no. 6765, p. 103-108.
ROTEM, R., HEYFETS, A., FINGRUT, O., BLICKSTEIN, D., SHAKLAI, M. and FLESCHER, E., 2005. Jasmonates: novel anticancer agents acting directly and selectively on human cancer cell mitochondria. Cancer Research, vol. 65, no. 5, p. 1984-1993.

SALCEDO R., ZHANG, X., YOUNG, HA., MICHAEL, N., WASSERMAN, K., MA, WH., MARTINS-GREEN, M., MURPHY, WJ. and OPPENHEIM, JJ., 2003. Angiogenic effects of prostaglandin $\mathrm{E}_{2}$ are mediated by up-regulation of CXCR4 on human microvascular endothelial cells. Blood, vol. 102, no. 6, p. 1966-1977.

SU, JL., SHIH, JY., YEN, ML., JENG, YM., CHANG, CC., HSIEH, CY., WEI, LH., YANG, PC. and KUO, ML., 2004. Cyclooxygenase-2 induces EP1- and HER-2/Neu-dependent vascular endothelial growth factor-C up-regulation: a novel mechanism of lymphangiogenesis in lung adenocarcinoma. Cancer Research, vol. 64, p. 554-564.

SUBBARAMAIAH, K., LIN, DT., HART, JC. and DANNENBERG, AJ., 2001. Peroxisome proliferator-activated receptor $\gamma$ ligands suppress the transcriptional activation of cycloxygenase-2. Journal of Biological Chemistry, vol. 276, no. 15 , p. $12440-12448$.

SCHMELZ, EA., ENGELBERTH, J., ALBORN, HT., O'DONNELL, P., SAMMONS, M., TOSHIMA, H. and TUMLINSON III, JH., 2003. Simultaneous analysis of phytohormones, phytotoxins, and volatile organic compounds in plants. Proceedings of the National Academy of Sciences of the United States of America, vol. 100, no. 18, p. 10552-10557.

SIMMONS, DL., BOTTING, RM. and HLA, T., 2004. Cycloxygenase isozymes: the biology of Prostaglandin synthesis and inhibition. Pharmacological Reviews, vol. 56, no. 3, p. 387-437.

STRAUS, DS., PASCUAL, G., LI, M., WELCH, JS ., RICOTE, M., HISIANG, C., SENGCHANTHALANGSY, LL., GHOSH, G. and GLASS, CK. 2000. 15-deoxy- $\Delta$ 12,14-prostaglandin $\mathrm{J} 2$ inhibits multiple steps in the NF- $\mathrm{KB}$ signaling pathway. Proceedings of the National Academy of Sciences of the United States of America, vol. 97, no. 2, p. 4844-4849.

THURSTON, G., SURI, C., SMITH, K., McClAIN, J., SATO, TN., YANCOPOULOS, GD. and McDONALD, DM., 1999. Leakage-resistant blood vessels in mice transgenically overexpressing angiopoietin-1. Science, vol. 286, no. 5449, p. 2511-2514.

VOSSELER, CA. and WEBER, PC., 2003. Structural requirements of cyclopentenone prostaglandins to induce endothelial cell apoptosis. Biochemical and Biophysical Research Communications, vol. 307, no. 2, p. 322-326.

YOON, JC., CHICKERING, TW., ROSEN, ED., DUSSAULT, B., QIN, Y., SOUKAS, A., FRIEDMAN, JM., HOLMES, WE. and SPIEGELMAN, BM., 2000. Peroxisome ProliferatorActivated Receptor $\gamma$ target gene encoding a novel angiopoietinrelated protein associated with adipose differentiation. Molecular and Cellular Biology, vol. 20, no. 14, p. 5343-5349. 